\title{
Spatial clustering analysis of the foot-and-mouth disease outbreaks in Mato Grosso do Sul state, Brazil - 2005
}

\author{
Análise de aglomeração espacial de focos de febre aftosa no Estado de Mato Grosso do Sul, \\ Brasil - 2005
}

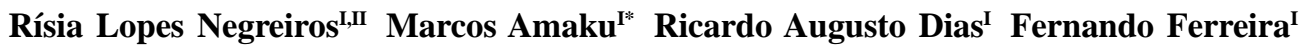 \\ João Crisostomo Mauad Cavalléro ${ }^{\text {III }}$ José Soares Ferreira Neto ${ }^{\mathrm{I}}$
}

\section{ABSTRACT}

In the southern region of Mato Grosso do Sul state, Brazil, a foot-and-mouth disease (FMD) epidemic started in September 2005. A total of 33 outbreaks were detected and 33,741 FMD-susceptible animals were slaughtered and destroyed. There were no reports of FMD cases in other species than bovines. Based on the data of this epidemic, it was carried out an analysis using the K-function and it was observed spatial clustering of outbreaks within a range of $25 \mathrm{~km}$. This observation may be related to the dynamics of foot-and-mouth disease spread and to the measures undertaken to control the disease dissemination. The control measures were effective once the disease did not spread to farms more than $47 \mathrm{~km}$ apart from the initial outbreaks.

Key words: foot-and-mouth disease, spatial clustering analysis, cattle, epidemiology, Brazil.

\section{RESUMO}

Uma epidemia de febre aftosa (FA), com casos apenas na espécie bovina, ocorreu no Estado do Mato Grosso do Sul, em setembro de 2005. Trinta e três focos foram detectados, e 33.741 animais suscetíveis à FA foram sacrificados e destruídos. Os dados dessa epidemia foram registrados, e uma análise utilizando a função $K$ foi realizada. Observou-se uma aglomeração espacial de focos dentro de um raio de $25 \mathrm{~km}$. Essa observação pode estar relacionada à dinâmica de espalhamento da FA e a medidas tomadas para controlar a disseminação da doença, embora essas medidas de controle tenham sido cruciais para a contenção da epidemia, não permitindo que a doença se espalhasse para fazendas com distâncias superiores a $47 \mathrm{~km}$ dos focos iniciais.

Palavras-chave: febre aftosa, análise de aglomeração espacial, Epidemiologia, Brasil.

\section{INTRODUCTION}

Foot-and-mouth disease (FMD) is a highly contagious viral disease of cloven-hoofed domestic and wild animals. It is most commonly spread by the movement of infected animals, and in a lesser degree by the movement of contaminated animal products and by-products. FMD may also be transmitted mechanically by contaminated vehicles and people.

The world distribution of foot-and-mouth disease reflects the global economic structure and, in general, as noted by RWEYEMAMU \& ASTUDILLO (2002), industrialized countries are free, while the disease is endemic in developing countries. FMD prevents many developing countries from participating in international trade. On the other hand, the increasing demand for animal protein can only be supplied with an enhanced participation of developing countries in livestock products trade (RWEYEMAMU \& ASTUDILLO, 2002).

As stated by CORREA MELO et al. (2002), a successful disease eradication strategy relies on high levels of vaccination, effectiveness of outbreak responses, and adequate control of animal movement. Besides, according to these authors, this strategy must be based on risk analysis methodology and must have a regional, not national, focus.

\footnotetext{
'Departamento de Medicina Veterinária Preventiva e Saúde Animal, Faculdade de Medicina Veterinária e Zootecnia (FMVZ), Universidade de São Paulo (USP). Av. Prof. Dr. Orlando Marques de Paiva, 87, 05508-270, São Paulo, SP, Brasil. E-mail: amaku@usp.br.*Autor para correspondência.

IIInstituto de Defesa Agropecuária do Estado de Mato Grosso, Cuiabá, MT, Brasil.

IIIAgência Estadual de Defesa Sanitária Animal e Vegetal de Mato Grosso do Sul, Campo Grande, MS, Brasil
} 
In 1987, the South American countries signed a Hemisphere Plan for the Eradication of FMD, and the number of clinical cases of FMD decreased significantly since then. During the early 1990s, an average of 766 cases was diagnosed per year in South America; by the end of the 1990s, the average number had fallen to 130 cases per year. In 2001, however, FMD reappeared in Argentina, Uruguay and Rio Grande do Sul state, Brazil (OIE, 2001).

The time series analysis of FMD outbreaks in Brazil showed that the disease was endemic until the 1980s, when the number of outbreaks decreased due to the identification and control of endemic areas and the use of higher quality vaccines (LYRA \& SILVA, 2004). In 1992, the Brazilian program to eliminate FMD was restructured by the Ministry of Agriculture, Livestock and Food Supply, producing an important decrease on FMD incidence (LYRA \& SILVA, 2004).

Spatial clustering analysis is a useful tool to study the spread of acute infectious diseases in animal populations. The identification of clusters might yield important information about the transmission and/ or control of such diseases (CARPENTER, 2001). In this work, it was used one of the methods available for testing clusters in space (CARPENTER, 2001), the Kfunction analysis (RIPLEY, 1977; BAILEY \& GATRELL, 1995), which is based on the comparison of the spatial aggregation of cases (farms with infected animals, in this case) and controls (farms with non-infected animals).

Spatial analysis studies of FMD outbreaks were carried out by several authors (e.g., GERBIER et al., 2002; WILESMITH et al., 2003; PEREZ et al., 2004; RIVAS et al., 2006). The identification of disease cluster was suggested to be important in diseases of rapid dissemination, such as FMD (RIVAS et al., 2006). In particular, RIVAS et al. (2006) and PEREZ et al. (2004), when analyzing data from the 2001 FMD epidemic in Uruguay and Argentina, observed disease cluster.

In the southern region of Mato Grosso do Sul state, Brazil, a FMD epidemic started on 26 September 2005. A total of 33 outbreaks were detected until November 2005 and 33,741 FMD-susceptible animals (32,549 cattle, 566 pigs, 626 sheep and goats) were slaughtered and destroyed (OIE, 2006). There were no reports of cases in species other than bovines. The control measures determined by the OIE such as quarantine, movement control inside the country, screening, zoning, stamping out and disinfection of infected premises were undertaken. In this research, it was carried out an analysis of spatial clustering of disease based on the data of this FMD epidemic.

\section{MATERIALS AND METHODS}

Surveillance activities were carried out In five municipalities (Eldorado, Iguatemi, Itaquiraí, Japorã and Mundo Novo) of the southern region of the State of Mato Grosso do Sul (Figure 1). There were 504,757 bovines in these five municipalities, according to the Brazilian livestock census published in 2006 (IBGE, 2006). In this research, the farms in which FMD cases were detected are called cases, whereas the remaining farms are called controls. The total number of controls within the study area was 2,134.

In the spatial analysis, it was considered the 33 outbreaks occurred in 2005, notified by the Brazilian Ministry of Agriculture, Livestock and Food Supply to the World Animal Health Organization (OIE, 2005b and previous reports). The geographic coordinates of the controls were provided by the local department of animal protection (Agência Estadual de Defesa Sanitária Animal e Vegetal de Mato Grosso do Sul, IAGRO/MS) and by the Brazilian Ministry of Agriculture, Livestock and Food Supply.

To test the hypothesis of spatial clustering of disease outbreaks, it was performed an analysis using the $K$-function (RIPLEY, 1977; BAILEY \& GATRELL, 1995). The $K$-function is defined as the expected number of further points within a distance $s$ of an arbitrary point, divided by the overall intensity of the points (ROWLINGSON \& DIGGLE, 1993). Spatial clustering analysis is a useful tool to study the spread of acute infectious diseases in animal populations.

$K$-functions estimates were computed for the cases $\left(K_{\text {case }}(s)\right)$ and the controls $\left(K_{\text {control }}(s)\right)$. The function $D(s)$, defined by $D(s)=K_{\text {case }}(s)-K_{\text {control }}(s)$, was also estimated. Positive values of $D(s)$ represent spatial aggregation of cases above the degree of spatial aggregation of controls attributable to environmental inhomogeneity (DIGGLE \& CHETWYND, 1991). Thus, significantly positive values of $D(s)$ would constitute evidence of FMD spatial clustering. The function $D(s)$ and the approximate 95\% confidence envelope were calculated using the Splancs library (ROWLINGSON \& DIGGLE, 1993) in R statistical package version 2.3.0 (R Development Core Team).

\section{RESULTS AND DISCUSSION}

Considering that 33 outbreaks were reported among 2,167 farm holdings in the studied area, it was estimated an attack rate of approximately $1.5 \%$, similar to the attack rate observed in the Pampeana region (1.4\%), where most of the cases (94\%) occurred in the 2001 FMD outbreak in Argentina (PEREZ et al., 2004). 


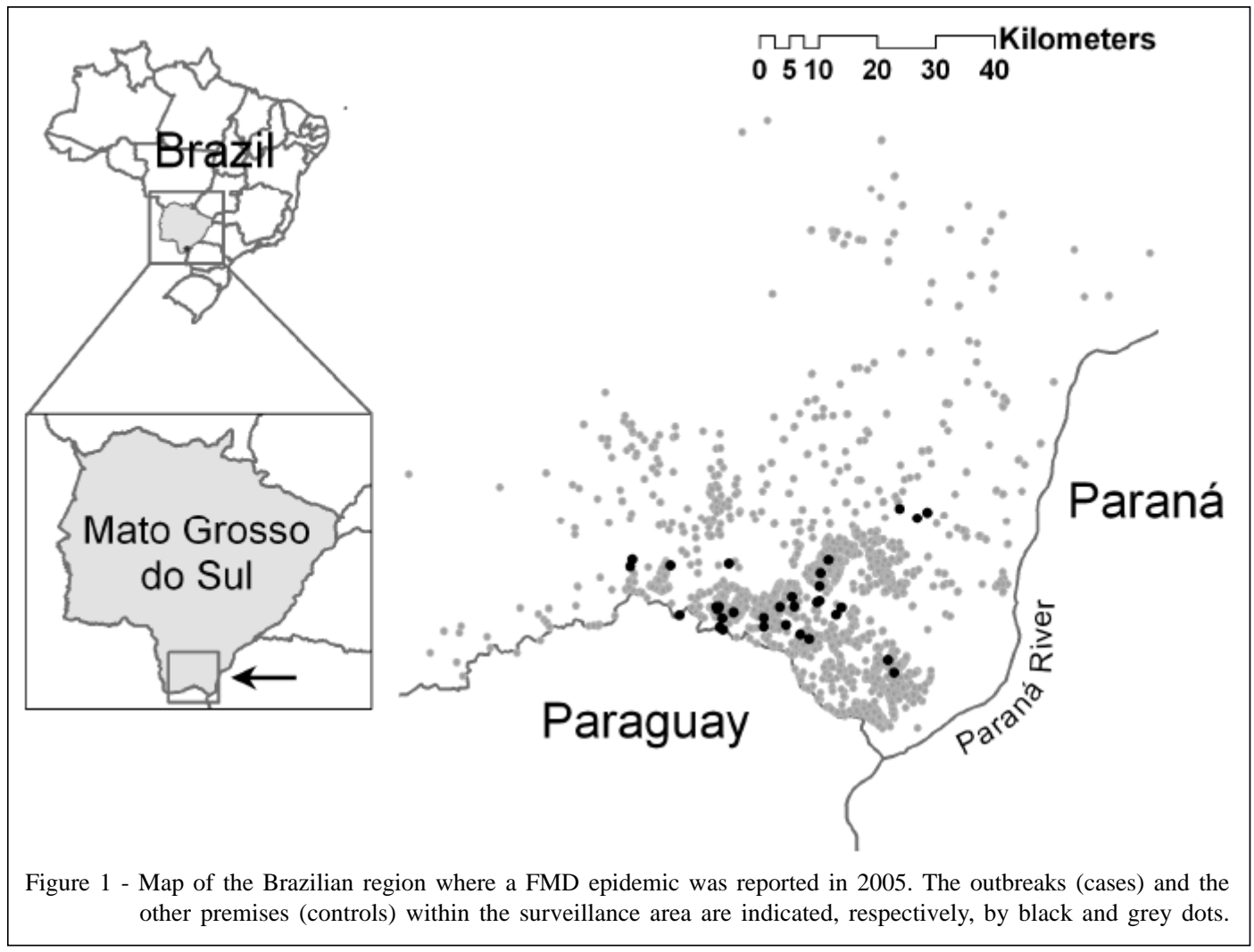

The results of the spatial clustering analysis can be seen in figure 2, that shows a graph of the function $D(s)=K_{\text {case }}(s)-K_{\text {control }}(s)$. It can be noted that, within a range of about $25 \mathrm{~km}$, the $D(s)$ values are above the upper limit of the approximate $95 \%$ confidence envelope, indicating that cases are more spatially clustered than controls. As in other FMD epidemics (PEREZ et al., 2004), these results may be related to the dynamics of FMD spread and to the intervention to control the disease dissemination. The control measures were probably crucial to contain the epidemic, and the disease did not spread to farms more than $47 \mathrm{~km}$ (maximum distance between two outbreaks) apart from the initial outbreaks.

In the region studied, there is predominance of beef cattle under extensive management (CHATE et al., 2009). It is possible that the network of animal movements between farms may have influenced the local transmission of FMD.

For a FMD epidemic that occurred in 1990 in the State of Santa Catarina, Brazil, FERREIRA (2000) estimated a minimum propagation speed of $491 \mathrm{~km}$ per year, which is equivalent to approximately $41 \mathrm{~km}$ per month or $1.36 \mathrm{~km}$ per day. In the present study, for instance, the first and the twenty-second notified outbreaks (OIE, 2005a) - located at the boundary of the infected area, but in opposite sides - were $45 \mathrm{~km}$ apart from each other, and were detected with a time-lag of 36 days. Dividing these figures, we obtain a rough estimate of $1.25 \mathrm{~km}$ per day for the speed of propagation, which is similar to the speed estimated by FERREIRA (2000).

RIVAS et al. (2006) observed that the data from the 2001 Uruguayan FMD epidemic were compatible with two hypotheses, namely: (i) disease clusters may be observed even in rapid disseminating epidemics; (ii) human mobility-related factors (demographic and road densities) may facilitate epidemic dispersal. It was also observed disease clusters in the FMD epidemic in the Mato Grosso do Sul state, confirming the importance of local spread for the transmission of FMD. Based on this observation, it may be recommend the intensification of the control measures in the neighborhood of an outbreak. Thus, the adequacy of the control strategy applied - which is based on movement control and zoning in the outbreak neighborhood, and also stamping out and disinfection of infected farms - is confirmed. 


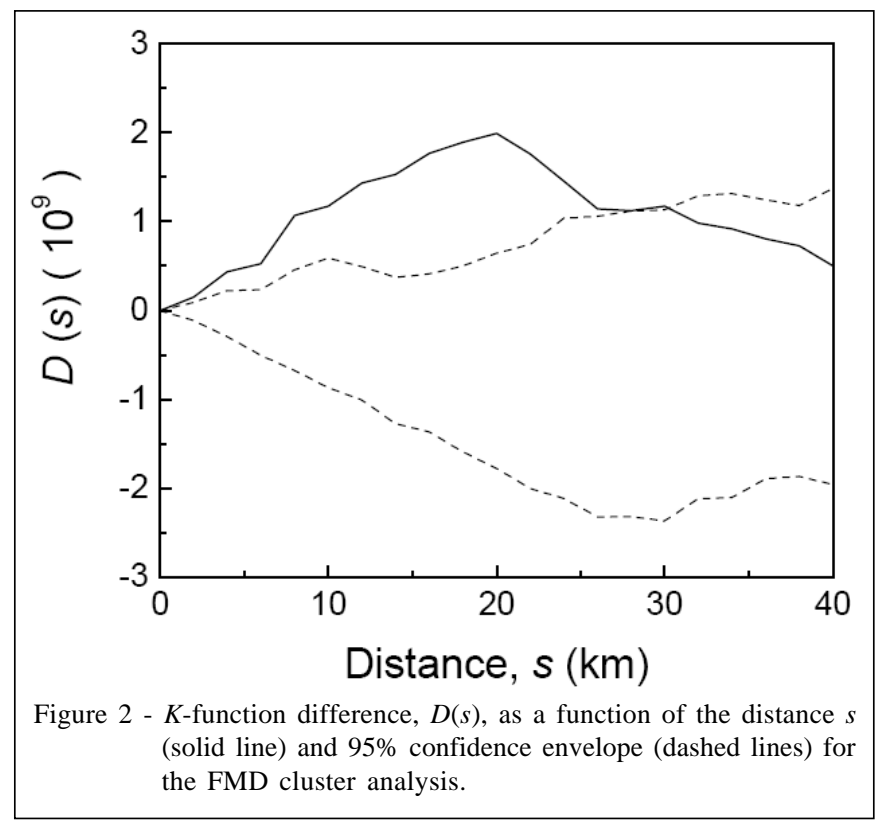

\section{CONCLUSION}

It was observed disease clusters in the FMD epidemic in Mato Grosso do Sul state, suggesting that FMD has spread locally between outbreaks. The control measures were effective once the disease did not spread to farms more than $47 \mathrm{~km}$ apart from the initial outbreaks. Thus, although the sources of the outbreaks are unknown according to the follow-up reports (OIE, 2005b and previous reports), factors related to the movement of animals, vehicles and people have probably contributed to the disease dissemination.

\section{ACKNOWLEDGEMENTS}

We are grateful to Pró-Reitoria de Pesquisa da Universidade de São Paulo, for the financial support (Projeto ProIP), to Agência Estadual de Defesa Sanitária Animal e Vegetal de Mato Grosso do Sul (IAGRO/MS), and to Ministério da Agricultura, Pecuária e Abastecimento do Brasil. We thank the anonymous referees for their comments and suggestions.

\section{REFERENCES}

BAILEY, T.C.; GATRELL, A.C. Interactive spatial data analysis. Harlow: Prentice Hall, 1995. 413p.

CARPENTER, T.E. Methods to investigate spatial and temporal clustering in veterinary epidemiology. Preventive Veterinary Medicine, v.48, p.303-320, 2001. Available from: <http:// dx.doi.org/10.1016/S0167-5877(00)00199-9>. Accessed: Aug. 17, 2009. doi:10.1016/S0167-5877(00)00199-9

CHATE, S.C. et al. Situação epidemiológica da brucelose bovina no Estado do Mato Grosso do Sul, Brasil. Arquivo Brasileiro de Medicina Veterinária e Zootecnia, in press, 2009.
CORREA MELO, E. et al. Review of the status of foot and mouth disease in countries of South America and approaches to control and eradication. Revue Scientifique et Technique de l'Office International des Épizooties, v.21, p.429-436, 2002.

DIGGLE, P.J.; CHETWYND, A.G. Second-order analysis of spatial clustering for inhomogeneous populations. Biometrics, v.47, p.1155-1163, 1991.

FERREIRA, F. Dinâmica espacial da febre aftosa em bovinos: um modelo matemático. 2000. $72 \mathrm{f}$. Tese (Doutorado em Saúde Pública) - Faculdade de Saúde Pública, Universidade de São Paulo, SP.

GERBIER, G. et al. A point pattern model of the spread of foot-and-mouth disease. Preventive Veterinary Medicine, v.56, p.33-49, 2002. Available from: <http://dx.doi.org/10.1016/S01675877(02)00122-8>. Accessed: Aug. 17, 2009. doi:10.1016/S0167-5877(02)00122-8.

INSTITUTO BRASILEIRO DE GEOGRAFIA E ESTATÍSTICA (IBGE). Censo Agropecuário 2006. Accessed: Apr. 20, 2009. Online. Available from: http://www.ibge.gov.br/home/estatistica/economia/ agropecuaria/censoagro/2006/defaulttab_censoagro.shtm.

LYRA, T.M.P.; SILVA, J.A. A febre aftosa no Brasil, 19602002. Arquivo Brasileiro de Medicina Veterinária e Zootecnia, v.56, p.565-576, 2004. Disponível em: <http:// www.scielo.br/pdf/abmvz/v56n5/a01v56n5.pdf> Acesso em: 11 set. 2009. doi:10.1590/S0102-09352004000500001.

OIE (WORLD ANIMAL HEALTH ORGANIZATION). Foot and mouth disease in Brazil. Follow-up report n. 8. Disease Information, v.18, n.44, p.403, 2005a. Accessed: Aug. 17, 2009. Online. Available from: http://www.oie.int/eng/info/ hebdo/AIS_46.HTM\#Sec2.

OIE (WORLD ANIMAL HEALTH ORGANIZATION). Foot and mouth disease in Brazil. Follow-up report n. 13. Disease Information v.18, n.51, p.532, 2005b. Accessed: Aug. 17, 2009. Online. Available from: http://www.oie.int/eng/info/ hebdo/AIS_39.HTM\#Sec8.

OIE (WORLD ANIMAL HEALTH ORGANIZATION). Number of new outbreaks by month according to the annual report, Foot and mouth disease, Americas, 2001. Accessed: Apr. 16, 2009. Online. Available from: http://www.oie.int/hs2/ sit_mald_incid_an.asp?c_mald=2\&c_cont $=2$ \&annee $=2001$.

OIE (WORLD ANIMAL HEALTH ORGANIZATION. Foot and mouth disease in Brazil. Follow-up report n. 18. Disease Information, v.19, n.11, p.227, 2006. Accessed: Aug. 17, 2009. Online. Available from: http://www.oie.int/eng/info/ hebdo/AIS_24.HTM\#Sec1.

PEREZ, A.M. et al. Epidemiological investigations of the 2001 foot-and-mouth disease outbreak in Argentina. Veterinary Record, v.154, p.777-782, 2004.

RIPLEY, B.D. Modelling spatial patterns (with discussion). Journal of the Royal Statistical Society Series B, v.39, p.172-212, 1977. 
RIVAS, A.L. et al. Human-mediated foot-and-mouth disease epidemic dispersal: disease and vector clusters. Journal of Veterinary Medicine B, v.53, p.1-10, 2006. Available from: <http://dx.doi.org/10.1111/j.1439-0450.2006.00904.x>. Accessed: Aug. 17, 2009. doi: 10.1111/j.1439-0450.2006.00904.x.

ROWLINGSON, B.S.; DIGGLE, P.J. Splancs: spatial point pattern analysis code in S-Plus. Computers and Geosciences, v.19, p.627-655, 1993.
RWEYEMAMU, M.M.; ASTUDILLO, V.M. Global perspective for foot and mouth disease control. Revue Scientifique et Technique de l’Office International des Épizooties, v.21, p.765-773, 2002.

WILESMITH, J.W. et al. Spatio-temporal epidemiology of footand-mouth disease in two counties of Great Britain in 2001. Preventive Veterinary Medicine, v.61, p.157-170, 2003. Available from: <http:/ /dx.doi.org/10.1016/j.prevetmed.2003.08.002>. Accessed: Aug. 17, 2009. doi: 10.1016/j.prevetmed.2003.08.002. 